\title{
The Zrinski-Frankopan Conspiracy as a National Sacrificial Narrative
}

Dukić, Davor

Source / Izvornik: Frontiers of Narrative Studies, 2018, 4, 146 - 157

Journal article, Published version

Rad u časopisu, Objavljena verzija rada (izdavačev PDF)

https://doi.org/10.1515/fns-2018-0013

Permanent link / Trajna poveznica: https://urn.nsk.hr/urn:nbn:hr:131:319767

Rights / Prava: In copyright/Zaštićeno autorskim pravom.

Download date / Datum preuzimanja: 2023-04-26

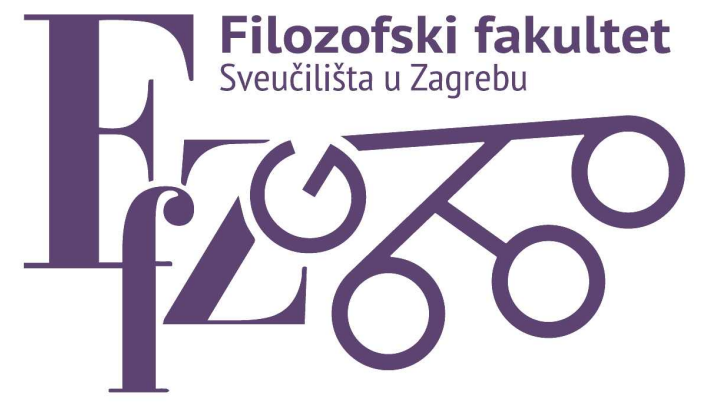

Repository / Repozitorij:

ODRAZ - open repository of the University of Zagreb Faculty of Humanities and Social Sciences
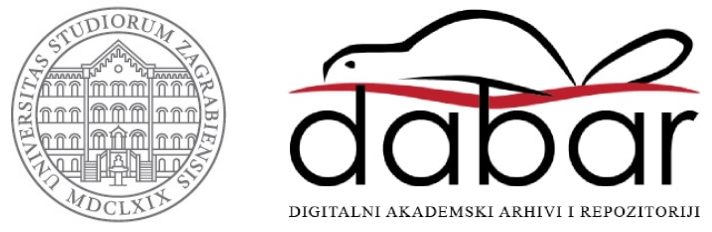


\title{
Davor Dukić* \\ The Zrinski-Frankopan conspiracy as a national sacrificial narrative
}

\author{
https://doi.org/10.1515/fns-2018-0013
}

The topic of this paper concerns the representations of the Zrinski-Frankopan (Zriny Frangipani) Conspiracy in five Croatian dramas, written and/or performed between 1900 and 2010, in the four different political constellations: in the late Habsburg Monarchy, in the early monarchist Yugoslavia, i.e. in the Kingdom of Serbs, Croats and Slovenes, in the Socialist Yugoslavia and finally in the modern independent Croatian state. The Zrinski-Frankopan Conspiracy is a sacrificial narrative par excellence in the Croatian culture as literary sources often directly refer the Conspiracy's actors as martyrs. Therefore this constitutes an interesting subject for this thematic section.

The basic methodological problem in this analysis is how to interpret a single literary text as a concretization of a historical myth which in itself represents a non-existent, intuitive, fluid construct. A critical reconstruction of a historical myth and/or a meta-narrative is an unrewarding, if not futile task, so it is therefore more fruitful to focus on its potential ruptures which undermine its semantic coherence. These ruptures can represent traumatic or at least uneasy loci in the historical meta-narratives, which makes them prone to interpretation.

The selected text analyzed here can be contextualized in three different frameworks of the national narration: firstly, in the historical myth about the Conspiracy, i.e. in a single narrative about one canonized historical event or about a cluster of events, which is the case with the Conspiracy; secondly, in the anti-Habsburg sub-narrative, as one of the narrative strands in the national historical meta-narrative (besides, for example, the anti-Turkish sub-narrative); and thirdly, in a more general national historical meta-narrative.

The analysis proposed here largely focuses on the first, "lowest" level, and the main methodological task is to discuss a relationship between the historical and literary discourse. The problem lies in the triple character of the historiography about the Conspiracy - it has served as the underlying source for three different intellectual endeavors: for the creation of the historical myth in the

\footnotetext{
*Corresponding author: Davor Dukić, Department for Croatian Language and Literature,
} University of Zagreb. Ivana Lučića 3, HR 10000 Zagreb, Croatia, E-Mail: ddukic@ffzg.hr 
second half of the nineteenth and the beginning of the twentieth century; for its literary variation and dissemination from its beginnings to today; and finally for the modern critical analysis of the historical myth.

The Zrinski-Frankopan Conspiracy is a series of related events in the seventeenth-century history of Croatia, which ends in the year 1671 with the execution of two leaders and most prominent members of the two most powerful magnate families of the time: Petar Zrinski (Zriny) and Fran Krsto Frankopan (Frangipani). Actually, the Conspiracy was triggered by dissatisfaction of some Hungarian and Croatian magnates with the Peace of Vasvár (1664) between the Habsburg Monarchy and the Ottoman Empire. The Peace, as a strategic move of the Viennese Court in the diplomatic struggle with France for the so-called Spanish Succession (Inheritance), was concluded without representatives of the Hungarian-Croatian part of the Monarchy and against their will. From their point of view, the Peace Treaty was a missed opportunity after the Ottoman defeat in the Battle of Saint Gotthard on 1 August 1664, to return the territories in southern Hungary, i.e. Slavonia and Bosnia occupied by the Ottomans in the fifteenth and sixteenth centuries. The first leader of the Conspiracy was Hungarian palatine Ferenc Wesselényi (hence the name "Wesselényi Conspiracy" in the Hungarian historiography) and one of the leading figures in the first stage of the Conspiracy was Croatian Ban Nikola Zrinski, who died in a hunting accident in November 1664. According to the official version it was a mischance, an accidental death caused by a wounded wild boar, whereas in the anti-Habsburg rumors it was an ordered assassination. Since 1667, after the death of Wesselényi, the leading positions in the Conspiracy were taken over by new Croatian Ban Petar Zrinski, Nikolas younger brother, and Lord Chief Justice of Hungary Ferenc Nádasdy. The Conspirators found the legal basis for their action in the Golden Bull of the Hungarian-Croatian King Andrew II from 1222 according to which the Hungarian and Croatian nobility had the right to rebel against the king if he violated their rights guaranteed by the same edict. King of France Louis XIV was the main foreign supporter of the Conspiracy. Nikola Zrinski began a secret diplomatic communication with him, which was continued by his brother Petar, first via the French ambassador in Venice and then via the ambassador in Vienna. Another potential supporter was new King of Poland Michael I (Michał Korybut Wiśniowiecki), but Petar Zrinski's plan to thwart king's marriage with Austrian princess Eleonora, the sister of Leopold I, fell through. When Louis XIV improved relations with Austria, after the arrangement of the division of the Spanish Inheritance in 1668, he abandoned the Conspirators. The Viennese Court had uncovered the Conspiracy, so that Petar Zrinski repented before the King and received his forgiveness. Despite this, the Conspiracy was soon resumed. Petar Zrinski and his Hungarian fellows tried to find a new protector in the Ottoman sultan. Negotiations with him 
were partially conducted with the knowledge of the Viennese Court, but when the Court realized that Zrinski and Frankopan were ready to replace the supremacy of the Habsburg emperor with the Ottoman sultan, it launched an attack with troops from the Croatian Military Frontier. Zrinski and Frankopan gave up armed resistance and tried to justify themselves before Leopold I. They went to Vienna, spent a year there and in Wiener Neustadt and, after the trial, were sentenced to death by decapitation, which occurred on 30 April 1671 (Cf. Šišić, Šidak).

Immediately after the execution of the Conspirators, the Viennese Court published the official version of the Conspiracy in several languages, which was for a long time the most influential source on the subject matter in European public domain. ${ }^{1}$ The parallel publication written in Latin and printed in Venice, that promoted the interests of the Conspirators, went undetected. ${ }^{2}$ Anyway, differences in the evaluation of the Conspiracy in Hungary and Croatia in the early modern period seem to be significant. In the Hungarian literary culture in the last quarter of the seventeenth century, there are some pro-Conspiracy poems written in Latin (Šidak 1972: 6); on the other hand, in Croatian contemporary sources there are several poems in Croatian, where the Conspirators are strongly condemned, especially Katarina Zrinski, Petar's wife and Frankopan's sister, who is represented in a misogynistic way as an ambitious instigator of the rebellion and a wannabe Croatian queen (Matić).

For almost two centuries the Conspiracy was almost forgotten in the Croatian culture. Its transformation into a historical myth occurred in the second half of the nineteenth century. This interpretative turn began at the time of the $300^{\text {th }}$ anniversary celebration of the Siege of Szigetvár in 1566 and the heroic death of Nikola Šubić Zrinski, the commander of the defenders and the ancestor of Nikola and Petar Zrinski. For Ante Starčević, the co-leader of the nationalist Party of Rights, the death of Nikola Šubić Zrinski was only an example of the pointless sacrifice for foreign interests. Just a few years later, around 1871, there was an occasion to celebrate the $200^{\text {th }}$ anniversary of the Conspiracy, i.e. its final end. A consensus about the meaning of the Conspiracy in the national history was very wide in an otherwise politically divided Croatian public opinion, even though a

1 The original German title reads: "Ausführliche und Warhafftige Beschreibung, wie es mit denen Criminal-Prozessen und darauf erfolgten Executionen, wider die drey Grafen Frantzen Nadaßdi, Peter von Zrin und Frantz Christophen Frangepan eigentlich hergangen” (Šidak 1972: 6).

2 Austriaca austeritas in qua ostenditur: quibus modis \& quo jure florentissimum quondam liberrimumque Hungariae regnum an 1670. armis regiis infestatum, et quod cornitatus ditionis regiae concemit defacto occupatum sit (Šidak 1972: 6). 
positive attitude toward the Conspiracy could have hardly been regarded as political opportunism in the Habsburg Monarchy. Based on the discourse about the Conspiracy - initiated by a relatively rapid growth of critical historical knowledge, which culminated with Ferdo Šišić's monograph published in 1908 (Šidak 1972: 8-14) - very soon there arose a typical nationalist narrative, which includes or implies some elements of the great Croatian historical narrative such as: a) a continuity of foreign rule since the Middle Ages; b) the preservation of statehood in the central parts of the country under the rule of the elected HungarianCroatian king, who since 1527 came from the Habsburg dynasty; ${ }^{3}$ c) the status of Croatian lands as ante murale christianitatis, which is the central point of the antiTurkish sub-narrative; d) the participation of Croatian soldiers in wars outside the Croatian lands as a fight for foreign interests; and finally e) the assumption about a continuous existence of common interests of Croatian nobility and common people, which is a very important point for this discussion.

Nevertheless, even the early historiographic representations of the Conspiracy could not be easily transformed into a coherent historical myth about the Conspirators as "heroes" and "martyrs" because of at least three potential ruptures related to three unpleasant facts. First, the most controversial episode of the Conspiracy was the collaboration with the Ottoman Empire, an act that is incompatible not only with the anti-Turkish (sub)narrative, but also with the tradition of both magnate families and even with the cause of the Conspiracy, i.e. with the dissatisfaction of Hungarian and Croatian magnates with the Peace Treaty of Vasvár. Second, according to historical sources the behavior of Petar Zrinski and Fran Krsto Frankopan during the investigation was not that heroic. Just as other arrested participants of the Conspiracy (e.g. F. Nádasdy) they too accused each other, which is suggestive of an image of a weakling and a liar (see Šišić, 1908). And third, the Conspirators gained almost no support from the rest of the Croatian nobility and from the domestic Catholic Church, which rejected the broad national character of their struggle (even if the anachronism of the seventeenthcentury concept of national identity is ignored). To preserve the myth of the Conspiracy, the authors of its literary representation could not conceal these unpleasant facts that were openly discussed in historiography: rather, they found the ways to make them acceptable.

3 According to this concept, the Croatian lands under the rule of the Ottoman Empire and the Republic of Venice - Slavonia and Dalmatia - are considered as occupied territories and the rest as reliquiae reliquiarum olim magni et inclyti regni Croatiae / remnants of the remnants of the once great and glorious Kingdom of Croatia. 
The analysis which follows addresses the following issues in relation to each dramatic narrative of the Conspiracy:

- How do they deal with the three above mentioned ruptures or uneasy historical facts?

- How the cause and/or goal of the Conspiracy are represented?

- What is the meaning of sacrifice/martyrdom in drama as a whole?

- Are there any traces of contemporary ideologies, i.e. political opportunism?

The first drama in the Croatian twentieth-century literature dedicated to the Conspiracy was Petar Zrinski: Historical drama in five acts (Petar Zrinski: historička drama u pet činova) by Eugen Kumičić, published in 1901, which premiered a year earlier. It was performed 13 times until 1914, with the reaction of the audience at times comparable to political rallies (Batušić 1971: 34-36). Eugen Kumičić (1850-1904), a prominent novelist and an active politician of the Party of Rights, the author of the first novel about the Conspiracy with the simple title The Zrinski-Frankopan conspiracy (Urota zrinsko-frankopanska, 1893), wrote the play by using some key-parts of his extremely popular and influential novel. His work is still a good example of the nineteenth-century historical drama, i.e. of the tendentious use of historical factuality in a literary text. Furthermore, the drama includes almost all key elements of the historical myth about the Conspiracy, or rather, it is one of the most important sources for creation and reconstruction of that myth. The cause of the Conspiracy is the Peace Treaty of Vasvár, while its goal is the liberation of the Croatian territories occupied by the Ottomans, as well as the liberation of the Military Border of the Croatian lands, which is considered a territory occupied by German commanders and soldiers. The Conspiracy has therefore a legal foundation. The historical and contemporary fate of Croatia is represented as antemurale christianitatis. The collaboration of the Conspirators with the Ottomans is the central motif of the drama. It is presented as an action initiated and supported by King Leopold I - as a kind of counter-espionage - and by Fran Bukovački, Petar Zrinski's captain and not Zrinski himself. On the other hand, the motif of the mutual accusation is peripheral and presented as a trick of the investigators. The allusion that Nikola Zrinski was killed by human hands is the leitmotif of the drama. The theme of martyrdom is connected with the whole country as antemurale christianitatis, and the cause of martyrdom of the Conspirators is found in their love for Croatia and in their loyalty to the king. The goal of their self-sacrifice is projected into the future as the idea of national liberation since they realize that they have been abandoned by their own people. The concrete suffering of the Conspirators is presented in a relatively short last act, with two important motifs of this theme: a farewell letter of Petar Zrinski to his wife Katarina and the horrendous death of Petar Zrinski - the executioner mana- 
ged to decapitate him only after three strokes. ${ }^{4}$ Unlike the later dramas about the Conspiracy, almost all characters in the play belong to the group of the Conspirators and their followers.

The second drama in this corpus, In Wiener Neustadt: An epilogue to the Zrinski-Frankopan tragedy in one act (U Bečkom Novom Mjestu: Epilog zrinskofrankopanskoj tragediji u jednom činu), was written by Milan Ogrizović (18771923). It premiered in 1921 in the Croatian National Theatre in Zagreb, as a partial winner of the contest for the best full-evening performance about the Conspiracy in honor of its $250^{\text {th }}$ anniversary. ${ }^{5}$

The drama is set in Wiener Neustadt on the last day of the trial against the Conspirators, at the very end of April, $1671 .^{6}$ The historical factuality in this drama - the first one published after Šišić's 1908 monograph on the Conspiracy is even more emphasized than in Kumičić's text, especially in its two unpublished acts. The two uneasy motifs - the collaboration with the Ottomans and the mutual accusation of the Conspirators - are introduced already in the first scene of the official version, and are presented in a similar way as in Kumičić. The Collaboration with the Ottomans is presented as at least a partially coordinated strategy between the Viennese Court and Zrinski towards the Ottomans, while the second motif builds on the investigators' swindling. The legitimacy of the Conspiracy is here explicitly expressed by mentioning the Golden Bull of Andrew II. However, there are major and more significant differences between Kumičić's and Ogrizović's text. Besides the Conspirators there are a few important characters from the Viennese Court, such as the investigators Hocher and Abele, the Prime Minister Lobkowitz, the main opponent of Petar Zrinski, the confessor of the emperor Oton Müller and Emperor Leopold I himself. The Emperor is presented as a hesitant ruler, inclined to forgive the Conspirators, which received negative criticism by contemporary theatre critics (S. Batušić 1971: 38). The most surprising feature of

4 The last act of the drama was performed six times between 1920 and 1928 as a special performance, usually on the day of the execution in Wiener Neustadt on 30 April (S. Batušić 1971: 36; N. Batušić 1993: 165-166).

5 The author and director of the Theatre were not satisfied with the integral version of the drama in three acts entitled The breakdown of the conspirators (Slom urotnika), so only the last act was submitted to the contest, and subsequently performed and published. The first two acts were discovered later in the author's archives and remained unpublished until today. The official version was performed only twice in Zagreb in 1921 and once in Belgrade in 1928, but it was “discovered" by Histrion Theatre Company and premiered in Vienna in December 1991, during the Croatian War of Independence. Cf. S. Batušić 1971: 36-39; N. Batušić 1993: 167-168.

6 The first unpublished act takes place in Vienna before Christmas of 1669, and the second in Čakovec on 13 April 1670, when Zrinski and Frankopan go to Vienna (Rubin 1938: 128-129; N. Batušić 1993: 168). 
the play is a complete absence of pathetic emphasis on the martyrdom of the Conspirators, despite the fact that the final version deals with their last days. Instead, Zrinski calls for revenge:

Our death will shout to our progeny: never trust oppressors of your kin, because your faith will be paid with death and disgrace. (He raises his hands up), Revenge our chopped off heads! (Ogrizović 1921: 44)

This is an expressions of the contemporary Yugoslav political ideology that reappears several times in the text: when Zrinski talks about the "Slovenian fraternal lands" (27) and about the liberation from the Ottoman rule of "all peoples speaking our language" (36), or when Katarina in the second unpublished act says: "We are all one folk - from the Adriatic Sea to Thessaloniki" (N. Batušić 1993: 168). ${ }^{7}$

The next play in this chronologically structured analysis is also the most performed drama about the Conspiracy. It is Zrinski: A dramatic chronicle in two parts (Zrinjski: dramska kronika u dva dijela) by Tito Strozzi (1892-1970), which premiered on 30 April $1924 .^{8}$ It takes place in Čakovec, Vienna and Wiener Neustadt between 1670 and 1671. Strozzi's text shares common or similar motifs with Milan Ogrizović's text, such as the sacrifice of the Croatian people on the Bulwark of Christianity; the Golden Bull of Andrew II and the legitimacy of the rebellion; mutual accusation of the Conspirators due to tricks of the investigators; Petar Zrinski's call for revenge and characterization of Emperor Leopold I as a weakling. Unlike the first two texts analyzed here, the act of execution is not presented on stage, but only recounted in the last scene, with a lot of emotion and pathos, and in addition includes the reading of the complete farewell letter by Petar Zrinski to his wife, which Eugen Kumičić only mentions in his text. Strozzi's play introduces some new characters, such as the Historian (only in the second version) who explains some details of the dramatic content to the audience; two Conspirators of non-Croatian origin: the Hungarian magnate Nádasdy, presented in the second scene as tipsy, arrogant and distrustful to Zrinski, and as a denoun-

7 These traces of political opportunism may seem surprising because Milan Ogrizović was a member of the Croatian nationalistic Pure Party of Rights (Čista stranka prava), but on the other hand, he was born an Orthodox and showed tolerance towards the Serbs in the First World War. His son Bogdan Ogrizović was a member of the Communist Party of Yugoslavia. The Ustasha regime condemned him to death and executed him in 1943.

8 The first version of the play had 9 scenes and about 40 characters. It was performed seven times by the end of 1924 and remained unpublished. The second, a somewhat shortened version - with 6 scenes and 25 characters - premiered on the same day seven years later and was performed 21 times by 1937 (S. Batušić1971: 39-41; Vaupotić 1973: 109; N. Batušić 1993: 168-170). The latter version - published in 1935 and slightly revised in the 1965 edition - is analysed here. 
cer among the Conspirators; the German, i.e. the Styrian nobleman Tattenbach, a wooer of Katarina and her daughter; and finally the French ambassador in Vienna Gremonville, a loquacious, cynical diplomat.

Two details in the retelling of the Conspiracy in Strozzi's drama are particularly relevant for this comparative analysis: first, Katarina Zrinska figures as an instigator of the Conspiracy, driven by desire for the crown; and second, unlike Petar Zrinski, Fran Krsto Frankopan is open to cooperation with the Ottomans, but only when the soldiers of the Military Frontier under the command of the general Herberstein approach Čakovec.

The key peculiarity of the play is Petar Zrinski's comprehension of the concept of "nation" ("narod"). The motif is introduced in the first scene, in the speech of the Historian ("The glitter of the strange concept of the nation got imprinted into his soul too early, during some carnage with the Turks”, 19) and then - like a leitmotif - it is several time repeated in the text. Its appearance has a character of epiphany: in the middle of the battle against the Ottoman soldiers after the Peace of Vasvár, Petar Zrinski recognizes among the faces of the enemy, i.e. the Moslems, people similar to himself, people of the same nation:

And then Vienna concluded the cowardly Peace of Vasvár with the Turks. I stopped. And I turned. - In front of me I no longer saw Muhammad's grinning masks. I saw people just like me (21-22).

The early critics of the play overlooked (or ignored) the fact that Zrinski speaks about the Muslims (Bosniaks). Anyway, the motif of Zrinski's premature idea of nation solves two intrinsic problems of the myth about the Conspiracy: an anachronism of the national idea in the early modern period and the unpleasant fact about the lack of support from Croatian nobility and clergy. ${ }^{9}$

The original title of the penultimate drama in this paper, Navik on živi ki zgine pošteno (Forever lives he, who dies an honorable death) is a verse from Frankopan's poem "Call to arms" ("Pozvanje na vojsku”). ${ }^{10}$ The play was written by Ivan

9 It is interesting to note that Tito Strozzi - actor, director and playwright - played in both performances of his play: in the first version the role of Leopold, and in the second the role of Gremonville. In 1926 he also tried, albeit unsuccessfully, to make a film adaptation of the play about Zrinski. This play is part of his trilogy about national heroes: the medieval king Tomislav (Tomislav, 1944), Petar Zrinski, and the founder of the Illyrian Movement Ljudevit Gaj (Gaj, 1936).

10 The verse is engraved on the tomb of the Conspirators in the Zagreb Cathedral, where their remains were transported from Wiener Neustadt in 1919. Frankopan's literary work was discovered only in the second half of the nineteenth century, during the search for historical sources about the Conspiracy. On the other hand, in 1660 Petar Zrinski published a book in Venice entitled The siren of the Adriatic Sea (Adrianskoga mora sirena), which is a translation of the book in Hungarian written by his brother Nikola (Adriai tengernek Syrenaia, Vienna 1651), containing an 
Raos (1921-1987), an established writer at the time. It was performed 1971, in the year of the $300^{\text {th }}$ anniversary of the Execution in Wiener Neustadt and in the year of the rise and fall of the so-called Croatian Spring, the famous Croatian nationalist movement. ${ }^{11}$ The earlier mentioned similarities of the content between Milan Ogrizović's and Tito Strozzi's texts are also present in Ivan Raos's text, including the same timeframe and setting. The role of Katarina Zrinski in the Conspiracy as well as Frankopan's inclination to cooperate with the Ottomans are much more emphasized in this drama then in Strozzi's text. The obsession with the historical facts, as a constant feature in this corpus, remains also in this literary work. Many statements of the Conspirators, just like in all previously discussed dramas, could have been understood as nationalist allusions to the contemporary political constellation. A good example is a difference between the state and the homeland, with the latter being favored, expressed in one of Zrinski's speeches:

I did not betray anyone, not even the state, though every patriot has a duty to betray the state for the benefit of the homeland! (Raos 1971: 308)

The evaluative state/homeland dichotomy is applicable to the position of Croatia within the Habsburg Monarchy and within the socialist Yugoslavia. ${ }^{12}$

The most significant novelty in this play occurs in the penultimate scene. In a fever-induced daydream, Petar Zrinski participates as an investigator in a trial against the real investigators, together with his wife Katarina and his brother-inlaw Fran Krsto. The scene is filled with humor: for example, when Zrinski reads a letter, which somebody from the Viennese Court has sent to the wild boar, the future assassinator of Nikola Zrinski. But already in the next scene which is also the last scene, the play switches back to the dominant pathetic mode to show the execution of the Conspirators.

In Raos's drama, the figure of Zrinski is still idealized according to the former historical myth: he refuses to cooperate with the Ottomans, and sacrifices himself instead of his people without realizing that he has been betrayed by his own people and not only by the Hungarians.

extensive epic poem about the Siege of Szigetvár in 1566, which takes up the central part of the book.

11 The play was actually commissioned by the Croatian National Theatre, and premiered in the Frankopans' old town of Ozalj, but was performed only 13 times (N. Batušić 1993: 172-173).

12 The other two examples of political actualization are the motifs of the financial looting of Croatia by the Viennese Court (Lobkovic) (Zrinski: "Is Croatia created only to be looted by such people?!”; Raos 1971: 325); and the surplus of any broader political framework for Croatia (Zrinski: “We don't need anyone else but ourselves!”; Raos 1971: 316) 
The last and only Croatian play about the Conspiracy written in our century is A Chronicle of disappearance (Kronika nestajanja 2010) by Vladimir Stojsavljević (1950). ${ }^{13}$ The author relies on the reader's knowledge of the historical myth and therefore does not repeat the well-known motifs like the parting of Zrinski and Frankopan or their execution. On the other hand, the historical factuality is still strongly emphasized: Marko Forstall - Ferenc Rakoczy's secretary and a teacher of Petar's son Ivan Zrinski - appears as the author of the Chronicle, i.e. as a commentator of the events in the drama, which includes 49 scenes with a multitude of historical figures (F. Rakoczy, F. Bukovački, F. Nádasdy, Emperor Leopold I, Lobkowitz, Hocher, Montecuccoli, Gremonville, Tattenbach, etc.).

The main interpretive innovation of the historical myth comes from a dramatic view from the inside, i.e. from the significance of family. ${ }^{14}$ The play begins with Zrinski's jealous outburst to his wife Katarina - the strongest figure in the play - which will be later explained as a consequence of his impotence caused by congenital syphilis. However, his suspicion of his wife's infidelity will be confirmed in the course of action: Katarina's love affair with Styrian conspirator Erazmo Tattenbach, a motif that was only vaguely indicated by Strozzi, is explicitly thematised in this text.

The issue of the relationship of the Zrinskis and the Turks also includes some new features. Petar's captive Omer figures as a mediator of cultural values, as Ivan Zrinski's alternative teacher, who says he would rather visit Istanbul than Vienna. Instead of insisting on the mutual accusation during the investigation, Stojsavljević sets the problem of the relationship between Zrinski and Frankopan before the beginning of their cooperation in the Conspiracy, i.e. when Zrinski suspects Frankopan's patriotism because of his long stay in Italy where he found his young wife, Julia de Naro.

13 It is actually the forth drama about the Zrinski family by the same author. The first one, Katarina Zrinski of the Frankopans (Katarina Zrinska od Frankopana, 1992), deals with Katarina's last days in Čakovec after 1670 Easter and her husband's and brother's departure in Vienna. The title of the second one, Departure (Odlazak, 1996), refers to departure of Jelena Zrinski, Petar Zrinski's daughter, in Turkey with her second husband Imre Thököly. The third one, Nikola the Seventh (Nikola sedmi, 2008), is located in Čakovec in the late autumn of 1664, between the Peace Treaty of Vasvár and the death of Nikola Zrinski.

14 The first dominantly psychological treatment of the historical myth about the Conspiracy was a one-act drama The conspirators (Urotnici, 1984) written by Miro Gavran (1961). Petar Zrinski and Fran Krsto Frankopan are the only characters in the play; their dialogue in the night before the execution includes only a few historical facts with some counterfactual details. Hence, since the author ignores the tradition of literary treatment of the historical myth about the Conspiracy, his text is not included in this analysis. 
However, all these new motifs do not compromise the basis of the historical myth. Petar Zrinski is not presented as a betrayer, but his real adversary Lobkowitz embodies a diabolic figure: he concluded the Peace of Vasvár and initiated an anti-propaganda campaign against Katarina and the Conspirators with the help of the Jesuits, and it was he who planned to plunder the property of the Zrinskis and Frankopans to fill the empty Empire's treasury in order to conceal his own embezzlement of state money.

In her excellent article on the Zrinskis in the Croatian historiography, Nataša Štefanec remarks:

On reading Klaić and Mesić, one could say that Zrinski died defending family possessions, the king and the law, Christianity and the Croatian homeland - in that order. Later, especially in the 1990s, the order gets rearranged. (Štefanec 2009: 397) ${ }^{15}$

The quote, however, refers to Nikola Zrinski IV, the defender of Szigetvár, but the same could be said for Petar Zrinski. The order of importance in dramas analysed here is just the opposite. Moreover, the private matters in the plays are almost completely suppressed. Nevertheless, a constant feature of the dramas on Conspiracy is their obsession with historiography, i.e. with historical factuality. The three uneasy historical facts - the collaboration with the Ottoman Empire, the mutual accusation of Zrinski and Frankopan and the lack of support from Croatian nobility and clergy - are not omitted but resolved in a way that preserves the historical myth: Petar Zrinski is not an advocate of collaboration with the Ottomans, he and Frankopan accuse each other because of the investigators' swindling while the Croatian people (still) do not understand their struggle. In this sense, Zrinski and Frankopan are the political avant-garde, the predecessors of the nineteenth-century nationalists. And therein lies their tragedy and the unsettling meaning of their sacrifice for future national freedom.

Simplifications and political actualizations are necessary for the preservation of historical myths, which is confirmed by all here analysed dramas. But their conservatism is most noticeable in the motif of collaboration with the Ottomans. Only Tito Strozzi's play does not confirmed - essentially early modern - impossibility of imagining an open Christian-Islamic cooperation.

15 Vjekoslav Klaić (1849-1928) and Matija Mesić (1826-1878) are eminent Croatian historians of their time. Klaić published an elaborate historical survey entitled The history of Croats from the earliest times to the end of the $19^{\text {th }}$ century (Povijest Hrvata od najstarijih vremena do svršetka XIX. stoljeća, 1-5, Zagreb 1899-1911), while Mesić published the influential monograph The life of Nikola Zrinjski, the hero of Szigetvár (Život Nikole Zrinjskoga, sigetskoga junaka, 1866). 


\section{References}

Batušić, Nikola. 1993. Zrinski i Frankopani u hrvatskoj drami. Umjetnost riječi 3-4, XXXVII. 155181.

Batušić, Slavko. 1971. Zrinsko-frankopanska tema na pozornici. Kaj 9, IV. 30-42.

Blažević, Zrinka \& Suzana Coha. 2008. Zrinski i Frankopani - strategije i modeli heroizacije u književnom diskursu. Radovi Zavoda za hrvatsku povijest 40. 91-117.

Gavran, Miro. 1984. Urotnici. Zatočenici, 37-68. Zagreb: Quorum.

Kumičić, Evgenij [=Eugen], Ed. A. Barac. 1950. Petar Zrinski: historička drama u pet činova. Djela II, 7-80. Zagreb: Zora.

Matić, Tomo. 1962. Urota P. Zrinskoga i F. K. Frankopana u prigodnim hrvatskim pjesmama njihova doba. Građa za povijest književnosti hrvatske 28. 229-261.

Ogrizović, Milan. 1921. U Bečkom Novom Mjestu: Epilog zrinsko-frankopanskoj tragediji u jednom činu. Zagreb: Matica hrvatska.

Raos, Ivan. 1971. Navik on živi ki zgine pošteno (ljetopis tjeskobe u pet slika). Kolo 4, IX: 273336.

Rubin, Drago. 1938. Milan Ogrizović: život i rad. Zagreb: Knjižara Z. V. Vasić.

Stojsavljević, Vladimir. 2011. Kronika nestajanja. In Kronika nestajanja: drame o obitelji Zrinski, 161-267. Zagreb: Leykam international.

Strozzi, Tito. 1999. Zrinjski: dramska kronika u dva dijela. In A. Lederer (ed.), Drame, 16-61. Vinkovci: Riječ.

Šidak, Jaroslav. 1972. Urota zrinsko-frankopanska kao historiografski problem. Radovi Instituta za hrvatsku povijest 2. 5-21.

Šišić, Ferdo. 1908. Posljednji Zrinski i Frankopani na braniku domovine. Posljednji Zrinski i Frankopani, 9-123. Zagreb: Matica hrvatska.

Štefanec, Nataša. 2009. Zrinski family in the Croatian historiographic discourse: A case-study of the construction in national identity. In Wilhelm Kühlmann \& Gábor Tüskés. (eds.), Militia et Litterae: Die beiden Nikolaus Zrínyi und Europa, 391-410. Tübingen: Max Niemeyer Verlag.

Vaupotić, Miroslav. 1973. Zrinsko-frankopanska urota u hrvatskoj dramskoj književnosti. Radovi Zavoda za slavensku filologiju 13. 95-114. 